\title{
Research on Dynamic Monitoring and Early Warning Model of Fund for Power Grid Infrastructure Projects
}

\author{
Qian Gao ${ }^{1}$, Yuchun $\mathrm{Han}^{2}$, Junyi Yang ${ }^{1 *}$, Guiqin $\mathrm{Zhang}^{3}$, Yu Hong ${ }^{1}$, Cheng Ding ${ }^{2}$ and Weijie Cao ${ }^{4}$ \\ ${ }^{1}$ Development Planning Department, State Grid Jiangsu Electric Power Company, Nanjing, Jiangsu Province, 210024, China \\ ${ }^{2}$ Development Planning Department, State Grid Lianyungang Power Supply Company, Lianyungang, Jiangsu Province, 222004, China \\ ${ }^{3}$ Finance Department, State Grid Lianyungang Power Supply Company, Lianyungang, Jiangsu Province, 222004, China \\ ${ }^{4}$ Development Planning Department, State Grid Wuxi Power Supply Company, Wuxi, Jiangsu Province, 214000, China
}

\begin{abstract}
In order to strengthen the all-round and whole process management and control of the project, improve the quality of statistical data, support the high-quality development of the company and power grid, and identify the mismatch between the progress of fund payment and the progress of project site construction and cost accounting. Through the research on the dynamic monitoring and early warning model of power grid infrastructure project funds, the problems existing in the fund settlement and payment management of power grid project in the process of project implementation are accurately revealed, and the project fund payment risk is prevented.
\end{abstract}

\section{Introduction}

There is a mismatch between the progress of fund payment and the progress of project construction and the progress of cost accounting in power grid infrastructure projects. Too early or too late fund payment will cause supervision risk. Therefore, in order to prevent and control the problems existing in the fund payment link of power grid infrastructure projects and prevent the risk of fund payment progress, the fund payment law of power grid infrastructure projects of $35 \mathrm{kV}$ and above is studied, the progress and time point of fund payment in each link of project management process are controlled, and the dynamic monitoring and early warning model of fund for power grid infrastructure project is constructed. Monitor whether the actual fund progress is abnormal and strengthen the investment process control, accurately locate the abnormal fund progress of the project, and analyse the abnormal source in time. Improve the level of lean management and control in the whole process of the project.

\section{Construction of dynamic monitoring and early warning model of fund for power grid infrastructure projects}

According to the payment rules of each fund agreed in the contract of power grid project, we sort out the fund payment progress of each detailed cost in the milestone node. According to the budget structure of project WBS element and considering the influence of project budget balance, the detailed level cost is summarized upward at the milestone node fund payment progress, and the boundary value of the cumulative fund payment schedule of each level of milestone node is calculated. Considering the margin of the boundary value of the fund payment schedule at each level of milestone nodes, a reasonable interval is set up to construct a dynamic monitoring and early warning model for the capital of power grid infrastructure projects to monitor whether the actual fund payment progress is abnormal. 


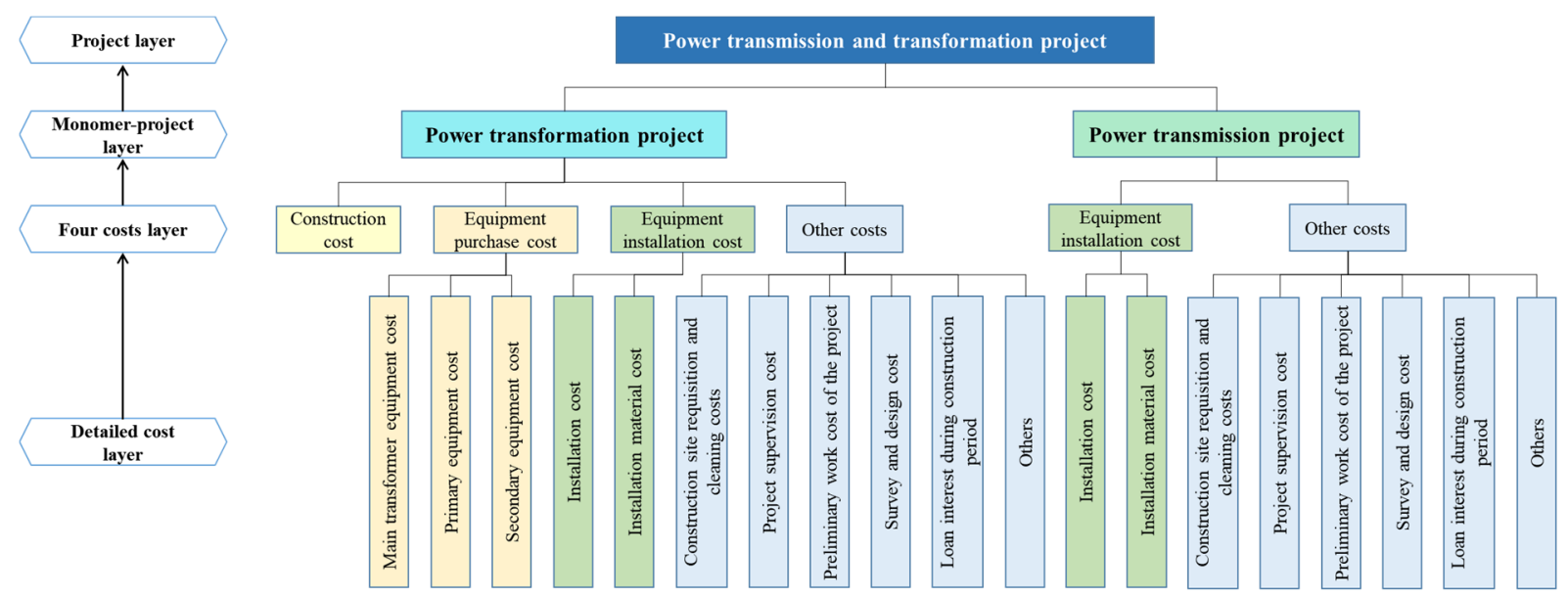

Figure 1. Budgetary estimate structure chart of power grid infrastructure project.

According to the idea of model construction, the specific steps of model construction are as follows:

- Sort out the accumulated fund payment progress of various detailed costs at the milestone node, and calculate the cumulative fund payment schedule of construction cost, equipment purchase cost, equipment installation cost and other costs at the milestone node.

- According to the fund payment progress of construction cost, equipment purchase cost, equipment installation cost and other costs at the milestone node, and the estimated proportion structure of these four costs, considering the project balance, the accumulated fund payment progress of single project at the milestone node after excluding the average project balance is calculated.

- The accumulated fund payment progress of milestone nodes of monomer-project layer calculated in the previous step is summarized and calculated to obtain the progress value of fund payment of project layer at each milestone node.
Take $\pm 10 \%$ of the progress value as the reasonable interval of actual fund payment for each milestone node. When the fund payment progress is not within the reasonable range, it will be given an early warning. In order to timely analyse the causes of early warning and prevent the risk of fund payment.

\section{Model building example}

\subsection{Basic case information}

Taking a $220 \mathrm{kV}$ transmission and transformation project as an example, the model construction and early warning results are analysed. The project includes a power transformation project and a power transmission project, and the budget estimates of the two individual projects account for $57 \%$ and $43 \%$ of the total investment respectively. The budgetary estimate structure of the four costs of two monomer-projects is shown in table 1.

Table 1. Budgetary estimate structure of monomer-project.

\begin{tabular}{c|c|c|c|c}
\hline Cost Item & Construction cost & Equipment purchase cost & Equipment installation cost & Other costs \\
\hline The power transformation project & $22 \%$ & $47 \%$ & $11 \%$ & $20 \%$ \\
\hline The power transmission project & -- & -- & $79 \%$ & $21 \%$ \\
\hline
\end{tabular}

The equipment installation cost includes installation cost and installation material cost. The proportion

structure of detailed expenses is shown in table 2.

Table 2. Detailed cost proportion structure of equipment installation cost.

\begin{tabular}{c|c|c}
\hline Cost Item & Installation cost & Installation material cost \\
\hline The power transformation project & $68 \%$ & $32 \%$ \\
\hline The power transmission project & $43 \%$ & $57 \%$ \\
\hline
\end{tabular}

The detailed items of other costs and the proportion structure of budget estimate are shown in table 3.

Table 3. Detailed cost proportion structure of other costs.

\begin{tabular}{c|c|c|c|c|c|c}
\hline Cost Item & $\begin{array}{c}\text { Construction site } \\
\text { requisition and } \\
\text { cleaning costs }\end{array}$ & $\begin{array}{c}\text { Project } \\
\text { supervision } \\
\text { cost }\end{array}$ & $\begin{array}{c}\text { Preliminary } \\
\text { work cost of the } \\
\text { project }\end{array}$ & $\begin{array}{c}\text { Survey and } \\
\text { design cost }\end{array}$ & $\begin{array}{c}\text { Loan interest during } \\
\text { construction period }\end{array}$ & Others \\
\hline The power transformation project & $35 \%$ & $6 \%$ & $6 \%$ & $17 \%$ & $9 \%$ & $27 \%$ \\
\hline The power transmission project & $43 \%$ & $4 \%$ & $4 \%$ & $17 \%$ & $9 \%$ & $23 \%$ \\
\hline
\end{tabular}




\subsection{Reasonable interval calculation of milestone node fund payment progress}

The construction of the model is based on the cumulative fund payment schedule of each cost in the milestone node. Through sorting out various types of standard contracts of power grid infrastructure projects in recent three years, the payment types corresponding to various expenses are clarified. The payment time and proportion of each cost are determined, and the fund payment progress of each cost in the project construction milestone node is obtained. Among them, the sorting out results of fund payment progress of power transformation project at milestone node are shown in table 4.

Table 4. The fund payment progress of each cost of power transformation project at milestone node.

\begin{tabular}{|c|c|c|c|c|c|c|c|}
\hline Cost Item & $\begin{array}{c}\text { Commencement } \\
\text { of works }\end{array}$ & \begin{tabular}{c|} 
Completion of \\
foundation construction
\end{tabular} & $\begin{array}{c}\text { Completion of } \\
\text { tower construction }\end{array}$ & $\begin{array}{c}\text { Completion of } \\
\text { stringing }\end{array}$ & $\begin{array}{c}\text { Project put into } \\
\text { operation }\end{array}$ & \begin{tabular}{|c|} 
Completion of \\
project settlement
\end{tabular} & $\begin{array}{c}\text { Expiration of project } \\
\text { warranty period }\end{array}$ \\
\hline \multicolumn{8}{|l|}{ Equipment installation cost } \\
\hline Installation cost & $20 \%$ & $90 \%$ & $90 \%$ & $90 \%$ & $90 \%$ & $97 \%$ & $100 \%$ \\
\hline Installation material cost & $10 \%$ & $10 \%$ & $85 \%$ & $85 \%$ & $95 \%$ & $95 \%$ & $100 \%$ \\
\hline \multicolumn{8}{|l|}{ Other costs } \\
\hline Construction site requisition and cleaning costs & $0 \%$ & $100 \%$ & $100 \%$ & $100 \%$ & $100 \%$ & $100 \%$ & $100 \%$ \\
\hline Project supervision cost & $0 \%$ & $0 \%$ & $0 \%$ & $0 \%$ & $0 \%$ & $100 \%$ & $100 \%$ \\
\hline Preliminary work cost of the project & $100 \%$ & $100 \%$ & $100 \%$ & $100 \%$ & $100 \%$ & $100 \%$ & $100 \%$ \\
\hline Survey and design cost & $30 \%$ & $30 \%$ & $30 \%$ & $30 \%$ & $30 \%$ & $97 \%$ & $100 \%$ \\
\hline Loan interest during construction period & $0 \%$ & $60 \%$ & $90 \%$ & $100 \%$ & $100 \%$ & $100 \%$ & $100 \%$ \\
\hline Others & $0 \%$ & $60 \%$ & $90 \%$ & $100 \%$ & $100 \%$ & $100 \%$ & $100 \%$ \\
\hline
\end{tabular}

Table 5 shows the sorting results of the progress of fund payment at the milestone node.

Table 5. The fund payment progress of each cost of power transmission project at milestone node.

\begin{tabular}{|c|c|c|c|c|c|c|c|}
\hline Cost Item & $\begin{array}{c}\text { Commencement } \\
\text { of works }\end{array}$ & $\begin{array}{c}\text { Completion of } \\
\text { foundation construction }\end{array}$ & $\mid \begin{array}{c}\text { Completion of } \\
\text { tower construction }\end{array}$ & $\begin{array}{c}\text { Completion of } \\
\text { stringing }\end{array}$ & $\begin{array}{c}\text { Project put into } \\
\text { operation }\end{array}$ & $\begin{array}{c}\text { Completion of } \\
\text { project settlement }\end{array}$ & $\begin{array}{l}\text { Expiration of project } \\
\text { warranty period }\end{array}$ \\
\hline \multicolumn{8}{|l|}{ Equipment installation cost } \\
\hline Installation cost & $20 \%$ & $90 \%$ & $90 \%$ & $90 \%$ & $90 \%$ & $97 \%$ & $100 \%$ \\
\hline Installation material cost & $10 \%$ & $10 \%$ & $85 \%$ & $85 \%$ & $95 \%$ & $95 \%$ & $100 \%$ \\
\hline \multicolumn{8}{|l|}{ Other costs } \\
\hline Construction site requisition and cleaning costs & $0 \%$ & $100 \%$ & $100 \%$ & $100 \%$ & $100 \%$ & $100 \%$ & $100 \%$ \\
\hline Project supervision cost & $0 \%$ & $0 \%$ & $0 \%$ & $0 \%$ & $0 \%$ & $100 \%$ & $100 \%$ \\
\hline Preliminary work cost of the project & $100 \%$ & $100 \%$ & $100 \%$ & $100 \%$ & $100 \%$ & $100 \%$ & $100 \%$ \\
\hline Survey and design cost & $30 \%$ & $30 \%$ & $30 \%$ & $30 \%$ & $30 \%$ & $97 \%$ & $100 \%$ \\
\hline Loan interest during construction period & $0 \%$ & $60 \%$ & $90 \%$ & $100 \%$ & $100 \%$ & $100 \%$ & $100 \%$ \\
\hline Others & $0 \%$ & $60 \%$ & $90 \%$ & $100 \%$ & $100 \%$ & $100 \%$ & $100 \%$ \\
\hline
\end{tabular}

According to the budget estimate structure of the project and the average balance rate of such projects, the payment schedule of the four costs of the power transmission and transformation project at the milestone node is calculated, and the reasonable interval of the cumulative fund payment progress of each monomerproject and the whole project at the milestone node is obtained. The reasonable interval of fund payment progress of the power transformation project at milestone node is shown in table 6 .

Table 6. Reasonable interval of cumulative fund payment progress of the power transformation project at milestone node.

\begin{tabular}{|c|c|c|c|c|c|c|c|c|c|c|c|}
\hline \multirow[b]{2}{*}{ No. } & \multirow[b]{2}{*}{ Entry name } & \multirow{2}{*}{$\begin{array}{c}\text { Proportion } \\
\text { of budget } \\
\text { estimate }\end{array}$} & \multirow{2}{*}{$\begin{array}{c}\text { Adjustment } \\
\text { coefficient } \\
\text { (1-Balance } \\
\text { rate })\end{array}$} & \multirow{2}{*}{$\begin{array}{c}\text { Proportion of } \\
\text { budget } \\
\text { estimate after } \\
\text { adjustment }\end{array}$} & \multicolumn{7}{|c|}{ Fund payment progress at milestone node } \\
\hline & & & & & $\begin{array}{c}\text { Commencement } \\
\text { of works }\end{array}$ & $\begin{array}{c}\text { Completion of } \\
\text { civil works }\end{array}$ & $\begin{array}{c}\text { Completion of } \\
\text { equipment } \\
\text { installation }\end{array}$ & $\begin{array}{c}\text { Completion } \\
\text { commissioning }\end{array}$ & $\begin{array}{c}\text { Project put } \\
\text { into operation }\end{array}$ & $\begin{array}{c}\text { Completion of } \\
\text { project } \\
\text { settlement }\end{array}$ & $\begin{array}{c}\text { Expiration of } \\
\text { project } \\
\text { warranty period }\end{array}$ \\
\hline Fund & $\begin{array}{l}\text { d payment progress at milestone nodes of } \\
\text { power transformation project }\end{array}$ & $100 \%$ & & $89 \%$ & $12 \%$ & $41 \%$ & $69 \%$ & $69 \%$ & $78 \%$ & $86 \%$ & $89 \%$ \\
\hline Reason & $\begin{array}{l}\text { nable interval of cumulative fund payment } \\
\text { progress of milestone node }( \pm 10 \%)\end{array}$ & & & & $(2 \% \sim 22 \%)$ & $(31 \% \sim 51 \%)$ & $(59 \% \sim 79 \%)$ & $(59 \% \sim 79 \%)$ & (68\% 88\%) & (76\% 96\%) & $(79 \% \sim 99 \%)$ \\
\hline 1 & Construction cost & $22 \%$ & $97 \%$ & $21 \%$ & $20 \%$ & $90 \%$ & $90 \%$ & $90 \%$ & $90 \%$ & $97 \%$ & $100 \%$ \\
\hline 2 & Equipment purchase cost & $47 \%$ & $87 \%$ & $41 \%$ & $10 \%$ & $10 \%$ & $70 \%$ & $70 \%$ & $90 \%$ & $95 \%$ & $100 \%$ \\
\hline 3 & Equipment installation cost & $11 \%$ & $\mathbf{9 8} \%$ & $11 \%$ & $17 \%$ & $17 \%$ & $84 \%$ & $84 \%$ & $84 \%$ & $96 \%$ & $100 \%$ \\
\hline 3.1 & Installation cost & $68 \%$ & $98 \%$ & $68 \%$ & $20 \%$ & $20 \%$ & $90 \%$ & $90 \%$ & $90 \%$ & $97 \%$ & $100 \%$ \\
\hline 3.2 & Installation material cost & $32 \%$ & $98 \%$ & $32 \%$ & $10 \%$ & $10 \%$ & $70 \%$ & $70 \%$ & $70 \%$ & $95 \%$ & $100 \%$ \\
\hline 4 & Other costs & $20 \%$ & $81 \%$ & $16 \%$ & $14 \%$ & $69 \%$ & $76 \%$ & $78 \%$ & $78 \%$ & $99 \%$ & $100 \%$ \\
\hline 4.1 & $\begin{array}{l}\text { Construction site requisition and } \\
\text { cleaning costs }\end{array}$ & $35 \%$ & $100 \%$ & $43 \%$ & $0 \%$ & $100 \%$ & $100 \%$ & $100 \%$ & $100 \%$ & $100 \%$ & $100 \%$ \\
\hline 4.2 & Project supervision cost & $6 \%$ & $100 \%$ & $8 \%$ & $0 \%$ & $0 \%$ & $0 \%$ & $0 \%$ & $0 \%$ & $100 \%$ & $100 \%$ \\
\hline 4.3 & Preliminary work cost of the project & $6 \%$ & $100 \%$ & $8 \%$ & $100 \%$ & $100 \%$ & $100 \%$ & $100 \%$ & $100 \%$ & $100 \%$ & $100 \%$ \\
\hline 4.4 & Survey and design cost & $17 \%$ & $100 \%$ & $21 \%$ & $30 \%$ & $30 \%$ & $30 \%$ & $30 \%$ & $30 \%$ & $97 \%$ & $100 \%$ \\
\hline 4.5 & Loan interest during construction period & $9 \%$ & $0 \%$ & $0 \%$ & $0 \%$ & $60 \%$ & $90 \%$ & $100 \%$ & $100 \%$ & $100 \%$ & $100 \%$ \\
\hline 4.6 & Others & $27 \%$ & $64 \%$ & $21 \%$ & $0 \%$ & $60 \%$ & $90 \%$ & $100 \%$ & $100 \%$ & $100 \%$ & $100 \%$ \\
\hline
\end{tabular}


The reasonable interval of fund payment progress of the power transmission project at milestone node is shown in table 7.

Table 7. Reasonable interval of cumulative fund payment progress of the power transmission project at milestone node.

\begin{tabular}{|c|c|c|c|c|c|c|c|c|c|c|c|}
\hline \multirow[b]{2}{*}{ No. } & \multirow[b]{2}{*}{ Entry name } & \multirow{2}{*}{$\begin{array}{c}\text { Proportion } \\
\text { of budget } \\
\text { estimate }\end{array}$} & \multirow{2}{*}{$\begin{array}{c}\text { Adjustment } \\
\text { coefficient } \\
\text { (1-Balance } \\
\text { rate) }\end{array}$} & \multirow{2}{*}{$\begin{array}{l}\text { Proportion of } \\
\text { budget } \\
\text { estimate after } \\
\text { adjustment }\end{array}$} & \multicolumn{7}{|c|}{ Fund payment progress at milestone node } \\
\hline & & & & & $\begin{array}{l}\text { Commencem } \\
\text { ent of works }\end{array}$ & $\begin{array}{l}\text { Completion } \\
\text { of foundation } \\
\text { construction }\end{array}$ & $\begin{array}{c}\text { Completion } \\
\text { of tower } \\
\text { construction }\end{array}$ & $\begin{array}{l}\text { Completion } \\
\text { of stringing }\end{array}$ & $\begin{array}{c}\text { Project put } \\
\text { into operation }\end{array}$ & \begin{tabular}{|c|}
$\begin{array}{c}\text { Completion } \\
\text { of project } \\
\text { settlement }\end{array}$ \\
\end{tabular} & $\begin{array}{c}\text { Expiration of } \\
\text { project } \\
\text { warranty period }\end{array}$ \\
\hline \multicolumn{2}{|c|}{$\begin{array}{c}\text { Fund payment progress at milestone nodes of } \\
\text { power transmission project }\end{array}$} & $100 \%$ & & $91 \%$ & $12 \%$ & $45 \%$ & $78 \%$ & $78 \%$ & $82 \%$ & $88 \%$ & $91 \%$ \\
\hline \multicolumn{2}{|c|}{\begin{tabular}{|c|}
$\begin{array}{c}\text { Reasonable interval of cumulative fund payment } \\
\text { progress of milestone node }( \pm 10 \%)\end{array}$ \\
\end{tabular}} & & & & $(2 \% \sim 22 \%)$ & $(35 \% \sim 55 \%)$ & $(68 \% \sim 88 \%)$ & $(68 \% \sim 88 \%)$ & $(72 \% \sim 82 \%)$ & $(78 \% \sim 98 \%)$ & $(81 \% \sim 100 \%)$ \\
\hline 1 & Equipment installation cost & $79 \%$ & $93 \%$ & $74 \%$ & $14 \%$ & $44 \%$ & $87 \%$ & $87 \%$ & $93 \%$ & $96 \%$ & $100 \%$ \\
\hline 1.1 & Installation cost & $43 \%$ & $93 \%$ & $43 \%$ & $20 \%$ & $90 \%$ & $90 \%$ & $90 \%$ & $90 \%$ & $97 \%$ & $100 \%$ \\
\hline 1.2 & Installation material cost & $57 \%$ & $93 \%$ & $57 \%$ & $10 \%$ & $10 \%$ & $85 \%$ & $85 \%$ & $95 \%$ & $95 \%$ & $100 \%$ \\
\hline 2 & Other costs & $21 \%$ & $83 \%$ & $17 \%$ & $11 \%$ & $74 \%$ & $79 \%$ & $81 \%$ & $81 \%$ & $99 \%$ & $100 \%$ \\
\hline 2.1 & $\begin{array}{l}\text { Construction site requisition and } \\
\text { cleaning costs }\end{array}$ & $43 \%$ & $100 \%$ & $52 \%$ & $0 \%$ & $100 \%$ & $100 \%$ & $100 \%$ & $100 \%$ & $100 \%$ & $100 \%$ \\
\hline 2.2 & Project supervision cost & $4 \%$ & $100 \%$ & $5 \%$ & $0 \%$ & $0 \%$ & $0 \%$ & $0 \%$ & $0 \%$ & $100 \%$ & $100 \%$ \\
\hline 2.3 & Preliminary work cost of the project & $4 \%$ & $100 \%$ & $5 \%$ & $100 \%$ & $100 \%$ & $100 \%$ & $100 \%$ & $100 \%$ & $100 \%$ & $100 \%$ \\
\hline 2.4 & Survey and design cost & $17 \%$ & $100 \%$ & $21 \%$ & $30 \%$ & $30 \%$ & $30 \%$ & $30 \%$ & $30 \%$ & $97 \%$ & $100 \%$ \\
\hline 2.5 & Loan interest during construction period & $9 \%$ & $0 \%$ & $0 \%$ & $0 \%$ & $60 \%$ & $90 \%$ & $100 \%$ & $100 \%$ & $100 \%$ & $100 \%$ \\
\hline 2.6 & Others & $23 \%$ & $65 \%$ & $18 \%$ & $0 \%$ & $60 \%$ & $90 \%$ & $100 \%$ & $100 \%$ & $100 \%$ & $100 \%$ \\
\hline
\end{tabular}

According to the proportion of the project budget in the total investment, the calculation results of the two monomer-projects are summarized to obtain the reasonable range of the fund payment progress of the project at the milestone node, as shown in table 8 .

Table 8. Reasonable interval of cumulative fund payment progress of XX power transmission and transformation project at milestone node.

\begin{tabular}{|c|c|c|c|c|c|c|c|c|c|}
\hline \multirow{2}{*}{ No. } & \multirow{2}{*}{ Milestone node } & \multirow{2}{*}{$\begin{array}{c}\text { Proportion } \\
\text { of budget } \\
\text { estimate }\end{array}$} & \multirow{2}{*}{$\begin{array}{c}\text { Commencement } \\
\text { of works }\end{array}$} & $\begin{array}{c}\text { Completion of } \\
\text { civil works }\end{array}$ & $\begin{array}{c}\text { Completion of } \\
\text { equipment } \\
\text { installation }\end{array}$ & $\begin{array}{c}\text { Completion } \\
\text { commissioning }\end{array}$ & \multirow{2}{*}{$\begin{array}{l}\text { Project put into } \\
\text { operation }\end{array}$} & \multirow{2}{*}{$\begin{array}{c}\text { Completion of } \\
\text { project } \\
\text { settlement }\end{array}$} & \multirow{2}{*}{$\begin{array}{c}\text { Expiration of } \\
\text { project warranty } \\
\text { period }\end{array}$} \\
\hline & & & & $\begin{array}{c}\text { Completion of } \\
\text { foundation } \\
\text { construction }\end{array}$ & $\begin{array}{c}\text { Completion of } \\
\text { tower } \\
\text { construction }\end{array}$ & $\begin{array}{c}\text { Completion of } \\
\text { stringing }\end{array}$ & & & \\
\hline \multicolumn{2}{|c|}{$\mathrm{XX}$ power transmission and transformation project } & $100 \%$ & $12 \%$ & $43 \%$ & $73 \%$ & $73 \%$ & $80 \%$ & $87 \%$ & $90 \%$ \\
\hline \multicolumn{2}{|c|}{$\begin{array}{l}\text { Reasonable interval of cumulative fund payment } \\
\text { progress of milestone node }( \pm 10 \%)\end{array}$} & & $(2 \% \sim 22 \%)$ & $(33 \% \sim 53 \%)$ & $(63 \% \sim 83 \%)$ & $(63 \% \sim 83 \%)$ & $(70 \% \sim 90 \%)$ & $(77 \% \sim 97 \%)$ & $(80 \% \sim 100 \%)$ \\
\hline 1 & The power transformation project & $57 \%$ & $12 \%$ & $41 \%$ & $69 \%$ & $69 \%$ & $78 \%$ & $86 \%$ & $89 \%$ \\
\hline 2 & The power transmission project & $43 \%$ & $12 \%$ & $45 \%$ & $78 \%$ & $78 \%$ & $82 \%$ & $88 \%$ & $91 \%$ \\
\hline
\end{tabular}

\subsection{Dynamic monitoring results and early warning analysis of $\mathrm{XX}$ power transmission and transformation project}

By comparing the actual payment progress of the project with the reasonable interval of the fund payment schedule of the milestone node calculated by the model, the cost items causing the fund payment progress early warning of the milestone node can be directly seen through the model warning results. To control the risk of fund payment by checking the cost items and reasons causing the early warning of the project. The early warning results of XX power transmission and transformation project are shown in figure 2. 


\begin{tabular}{|c|c|c|c|c|c|c|c|c|}
\hline \multirow{2}{*}{\multicolumn{2}{|c|}{ Milestone node }} & \multirow{2}{*}{$\begin{array}{l}\text { Commencement } \\
\text { of works }\end{array}$} & \multirow{2}{*}{\begin{tabular}{|c|}
$\begin{array}{c}\text { Completion of } \\
\text { civil works }\end{array}$ \\
$\begin{array}{c}\text { Completion of } \\
\text { foundation } \\
\text { construction }\end{array}$ \\
\end{tabular}} & \multirow{2}{*}{\begin{tabular}{|c|}
$\begin{array}{c}\text { Completion of } \\
\text { equipment } \\
\text { installation }\end{array}$ \\
$\begin{array}{c}\text { Completion of } \\
\text { tower } \\
\text { construction }\end{array}$ \\
\end{tabular}} & \multirow{2}{*}{\begin{tabular}{|c|}
$\begin{array}{c}\text { Completion } \\
\text { commissioning }\end{array}$ \\
$\begin{array}{c}\text { Completion of } \\
\text { stringing }\end{array}$ \\
\end{tabular}} & \multirow{2}{*}{$\begin{array}{c}\text { Project put into } \\
\text { operation }\end{array}$} & \multirow{2}{*}{$\begin{array}{c}\text { Completion of } \\
\text { project } \\
\text { settlement }\end{array}$} & \multirow{2}{*}{$\begin{array}{c}\text { Expiration of } \\
\text { project } \\
\text { warranty } \\
\text { period }\end{array}$} \\
\hline & & & & & & & & \\
\hline \multicolumn{2}{|c|}{$\begin{array}{l}\text { XX power transmission and transformation project } \\
\text { Reasonable interval of cumulative fund payment progress of } \\
\text { milestone node }( \pm 10 \%)\end{array}$} & $(2 \% \sim 22 \%)$ & $(33 \% \sim 53 \%)$ & $(63 \% \sim 83 \%)$ & $(63 \% \sim 83 \%)$ & $(70 \% \sim 90 \%)$ & $(77 \% \sim 97 \%)$ & $(80 \% \sim 100 \%)$ \\
\hline \multicolumn{2}{|c|}{$\begin{array}{l}\text { Actual fund payment schedule of } \mathrm{XX} \text { power transmission and } \\
\text { transformation project }\end{array}$} & $4 \%$ & $60 \%$ & $61 \%$ & $72 \%$ & $74 \%$ & $77 \%$ & $83 \%$ \\
\hline \multicolumn{2}{|l|}{ Early warning status } & O & O & O & O & O & O & O \\
\hline \multicolumn{2}{|c|}{$\begin{array}{c}\text { 1. The power transformation project } \\
\text { Reasonable interval of cumulative fund payment progress of } \\
\text { milestone node }( \pm 10 \%)\end{array}$} & $(2 \% \sim 22 \%)$ & $(31 \% \sim 51 \%)$ & $(59 \% \sim 79 \%)$ & $(59 \% \sim 79 \%)$ & $(68 \% \sim 88 \%)$ & $(76 \% \sim 96 \%)$ & $(79 \% \sim 99 \%)$ \\
\hline \multicolumn{2}{|c|}{ Actual fund payment schedule of power transformation project } & $4 \%$ & $56 \%$ & $56 \%$ & $67 \%$ & $72 \%$ & $78 \%$ & $87 \%$ \\
\hline \multicolumn{2}{|l|}{ Early warning status } & ○ & O & 0 & 0 & O & 0 & O \\
\hline \multirow{4}{*}{$\begin{array}{l}\text { Actual payment progress and early warning } \\
\text { status of various expenses.* } \\
\text { (*The red font indicates that the fund payment } \\
\text { progress is higher than the reasonable range, } \\
\text { and the yellow font indicates that the payment } \\
\text { progress is lower than the reasonable range. ) }\end{array}$} & Construction cost & $0 \%$ & $70 \%$ & $70 \%$ & $70 \%$ & $70 \%$ & $70 \%$ & $100 \%$ \\
\hline & $\begin{array}{l}\text { Equipment } \\
\text { purchase cost }\end{array}$ & $0 \%$ & $62 \%$ & $63 \%$ & $88 \%$ & $88 \%$ & $95 \%$ & $100 \%$ \\
\hline & $\begin{array}{l}\text { Equipment } \\
\text { installation cost }\end{array}$ & $0 \%$ & $82 \%$ & $82 \%$ & $82 \%$ & $100 \%$ & $100 \%$ & $100 \%$ \\
\hline & Other costs & $25 \%$ & $54 \%$ & $54 \%$ & $54 \%$ & $54 \%$ & $97 \%$ & $100 \%$ \\
\hline \multicolumn{2}{|c|}{$\begin{array}{l}\text { 2. The power transmission project } \\
\text { Reasonable interval of cumulative fund payment progress of } \\
\text { milestone node }( \pm 10 \%)\end{array}$} & $(2 \% \sim 22 \%)$ & $(35 \% \sim 45 \%)$ & $(68 \% \sim 88 \%)$ & $(68 \% \sim 88 \%)$ & $(72 \% \sim 92 \%)$ & $(78 \% \sim 98 \%)$ & $(81 \% \sim 100 \%)$ \\
\hline \multicolumn{2}{|c|}{ Actual fund payment schedule of power transmission project } & $4 \%$ & $64 \%$ & $65 \%$ & $76 \%$ & $76 \%$ & $77 \%$ & $79 \%$ \\
\hline \multicolumn{2}{|l|}{ Early warning status } & O & P & ○ & ○ & ○ & O & O \\
\hline \multirow{2}{*}{$\begin{array}{c}\text { Actual payment progress and early warning } \\
\text { status of various expenses.* }\end{array}$} & Installation cost & $6 \%$ & $81 \%$ & $81 \%$ & $97 \%$ & $97 \%$ & $97 \%$ & $100 \%$ \\
\hline & Other expenses & $0 \%$ & $76 \%$ & $93 \%$ & $94 \%$ & $96 \%$ & $100 \%$ & $100 \%$ \\
\hline
\end{tabular}

Figure 2. Dynamic monitoring and early warning results of XX power transmission and transformation project.

Taking the transformation project as an example, combined with the cost item of the transformation project early warning, the reasons of fund payment early warning are analysed. The milestone nodes of the actual fund payment progress of the transformation project are the completion of civil works and the completion of equipment installation. The main results are as follows.

- In the early stage of the project, the reason for the low progress of the actual funds is that the advance payment for the project construction and equipment purchase costs has not been paid. However, the high progress of other costs is due to the full payment of survey and design costs.

- There are two reasons for the high progress of fund payment at the time of civil works completion. One is that the payment progress of equipment purchase cost is higher than the theory due to the arrival of some materials in the civil works stage. The other is due to the high proportion of equipment installation engineering cost in the civil works stage.

- The reason for the high payment progress at the time point of equipment installation completion: the payment on arrival for all goods and materials agreed in the contract shall be paid at the equipment installation stage. However, due to the slow progress of payment for some materials, the payment progress of equipment purchase cost is lower than the reasonable range.

- The progress of payment for equipment purchase cost reached $88 \%$ at the time point of commissioning completion, which is due to the payment for material operation of some equipment that has been put into operation.

\section{Conclusion}

Through the dynamic monitoring and early warning model of fund for power grid infrastructure project, we can monitor the progress of fund payment in the whole process of the project, closely track and analyse the implementation of the fund payment progress of power grid project, accurately locate the abnormal progress of the project and analyse the abnormal source. The key risk prevention and control of power grid project fund management is integrated into the whole process of project construction. Ensure the safety of construction funds, realize the management requirements of "real-time control, lean and efficient" of power grid infrastructure projects, and improve the real-time control ability of lean capital payment in the whole process of the project.

\section{References}

1. He, Q. Z., Zhang, Z. Z., Zou, N., (2019) Controlling key nodes of fund management and strengthening fund risk control. China chief accountant, pp. 51-59.

2. Zhang, A. J., Jiao, W. F., (2020) Analysis on the fund safety management and risk control strategy of power grid enterprises. Technology and Economic Guide, pp. 247.

3. Chen, G. P., Zhou, C. C., Wang, M. W., etc. (2019) Financial risk management based on Resource Sharing Coordination Mechanism. State owned enterprise management, pp. 78-89.

4. Zhang, J., (2020) Optimization and improvement of investment budget control for power grid 
infrastructure projects. State Grid Finance, pp. 3942.

5. Guan, Y., (2018) Research on cost control of power grid infrastructure project from the perspective of life cycle. Economic outlook around Bohai Sea, pp. 151-152. 